\title{
PENGGUNAAN KLAUSA RELATIF PADA PEMBELAJAR BIPA DI UNIT PELAKSANA TEKNIS (UPT) BAHASA UNIVERSITAS SEBELAS MARET SURAKARTA
}

\author{
Anggun Melati Sari ${ }^{1,}$ Andayani' $^{2}$, Sumarlam $^{3}$ \\ ${ }^{1}$ Universitas Sebelas Maret Surakarta \\ anggun07melati@gmail.com \\ ${ }^{2}$ Universitas Sebelas Maret Surakarta \\ Bu_anda09@yahoo.co.id \\ ${ }^{3}$ Universitas Sebelas Maret Surakarta \\ sumarlamwd@gmail.com
}

\begin{abstract}
This study aimed to describe the use of relative clauses Indonesian learners for Foreign Speakers (BIPA) grade-level academic scholarship at the Technical Implementation Unit (UPT) Language of Sebelas Maret University. The subject matter is the form of the use of relative clauses and the types of errors in relative clause. The data used in this study is the form of oral's data and writing's data. The data derived from the oral-speech BIPA's learners in which there is relative clause while the writing's data derived from the sentences in BIPA learner's essay in which there is relative clause. The data were analyzed using agih methods and advanced technique of agih methods. The results of this study indicate that the use of relative clauses in BIPA learners using the perelative words "yang". Acquisition of the relative clauses that relativize the thermic elements and errors in the relative clause that removes the noun element occupying the highest level as well as describe the highest degree of mastery in relative clauses. This study concluded that the form of the use of relative clause also describe the mastery level of difficulty of each type of relative clause learners BIPA.
\end{abstract}

Keywords: clause, relative clause, Indonesian for foreign speakers (BIPA)

\section{PENDAHULUAN}

Penggunaan bahasa Indonesia bagi penutur asing (BIPA) seperti bidang pengajaran dan bidang lainnya menjadi daya tarik tersendiri bagi masyarakat. Kini, pengajaran BIPA telah diselenggarakan di berbagai perguruan tinggi. Sampai saat ini lebih 251 lembaga yang menyelenggarakan program BIPA dan ada 48 negara yang menyelenggarakan pengajaran BIPA dan diprediksi akan terus berkembang (Badan Pengembangan dan Pembinaan Bahasa Kementrian Pendidikan dan Kebudayaan, 2017). 
UU Nomor 24 Tahun 2009 tentang Bendera, Bahasa, dan Lambang Negara serta Lagu Kebangsaan telah menegaskan bahwa fungsi bahasa Indonesia sebagai bahasa resmi dalam komunikasi nasional bagi seluruh lapisan masyarakat. Selaras dengan UU tersebut maka tuntutan penggunaan bahasa Indonesia oleh penutur asing di dalam negeri akan semakin meningkat pada masa mendatang.

Pembelajaran bahasa ini sejalan dengan apa yang dikemukakan oleh Hedge (2002: 45) bahwa memelajari bahasa adalah untuk mengetahui bahasa itu dan dapat menggunakan pengetahuan berbahasanya ketika berkomunikasi dalam beragam tempat dan situasi. Bentuk komunikasi dalam bahasa terbagi menjadi dua, yakni komunikasi lisan dan tulis. Selaras dengan hal tersebut (Suhardi, 2000: 135-136) mengatakan bahwa bahasa Indonesia sebagai bahasa asing banyak diminati orang dari mancanegara yang bertujuan untuk keperluan berkomunikasi dengan bahasa Indonesia, untuk melanjutkan studi di Indonesia, untuk mengembangkan bisnis di Indonesia, untuk mendalami bahasa Indonesia, dan untuk mendalami kehidupan masyarakat dan budaya di Indonesia.

Banyak pembelajar BIPA yang memilih untuk belajar bahasa Indonesia di dalam sebuah lembaga, yakni universitas. Salah satunya, lembaga Unit Pelaksana Teknis (UPT) Bahasa Universitas Sebelas Maret. Mereka yang datang ke UPT pun berasal dari berbagai negara seperti Thailand, Vietnam, Timor Leste, Meksiko, Korea, Jepang, Polandia, dan Filipina. Dalam hal ini, pembelajar BIPA yang menjadi objek penelitian masuk di kelas darmasiswa level akademik.

Keragaman tujuan pembelajar BIPA tersebut tentu dijadikan salah satu bahan pertimbangan dan masukan untuk penyusunan kurikulum maupun silabus pembelajaran BIPA, termasuk bagaimana materi dan metode pembelajaran (Li, 2009: 57). Berdasarkan hasil wawancara prapenelitian kepada pengajar dan beberapa pembelajar BIPA, maka dapat ditemukan sebuah masalah berkaitan dengan penggunaan klausa relatif. Kenyataan yang dijumpai dalam pembelajaran BIPA adalah perbedaan latar belakang individu. Hal tersebut merupakan faktor penting yang membantu untuk mengidentifikasi penyebab munculnya gejala lingual dalam pemerolehan bahasa asing (Ellis, 2003: 73-78), dalam menguraikan pemerolehan klausa relatif perlu diperhitungkan kemungkinan perbedaan individual tersebut. Klausa relatif adalah klausa terikat yang diawali oleh pronomina relatif yang (Kridalaksana, 2008: 125) dan fungsinya mendeskripsikan nomina atau frasa nomina yang terdapat di dalam klausa utama (Decapua, 2008: 319). 
Perlu diketahui pula bahwa klausa relatif sama dengan klausa adjektival karena klausa relatif itu berfungsi sebagai kualifikator atau modifikator kontituen induk yang berupa nomina (Mallinson dan Blake, 1981: 264). Selain itu, Keenan dan Comrie (1977: 63-64) menjelaskan bahwa setiap objek sintaksis merupakan klausa relatif jika objek itu mengategorikan seperangkat hal menjadi dua tahap, yakni perangkat lebih besar yang disebut domain perelatifan, lalu membatasi dalam bagian yang lebih kecil dengan kalimat tertentu dan benar.

Sama halnya dengan pendapat di atas, Richards (1985: 23) mengatakan bahwa klausa adalah kumpulan beberapa kata yang mempunyai subjek dan kata kerja terbatas. Klausa dibagi menjadi dua jenis, yaitu klausa bebas dan klausa terikat seperti yang diungkapkan oleh Gucker (1966: 76). Secara gramatikal klausa bebas terdiri atas kata kerja terbatas sedangkan klausa terikat dapat terdiri atas kata kerja terbatas atau kata kerja tidak terbatas (Downing dan Locke, 2006: 13).

Apabila dilihat dari segi konstruksinya, klausa adalah bagian sintaksis yang mempunyai satu unsur. Konstruksi klausa adalah satu tagmemik yang mencakup hanya satu predikat Elson \& Pickett (1969: 64). Hal ini sejalan dengan pendapat Pike \& Pike (1977: 64) bahwa klausa merupakan sebuah konstruksi yang terdiri atas satu predikat saja. Klausa tersebut dibedakan menjadi klausa bebas dan klausa terikat (Cook, 1969: 67-73).

Sama halnya dengan konsep klausa di atas, klausa relatif merupakan bagian dari klausa. Klausa relatif merupakan klausa terikat yang memiliki unsur awal pronomina relatif yang (Kridalaksana, 2008: 125) dan fungsinya mendeskripsikan sebuah nomina atau frasa nomina yang terdapat di dalam klausa utama (Decapua, 2008: 319). Konstruksi klausa relatif terdiri atas dua komponen, yakni nomina inti (head noun) dan klausa relatif sebagai pewatasnya. Dalam bahasa Indonesia antara nomina inti dan klausa relatif dihubungkan dengan kata yang. Kata yang disebut kata perelatif atau pronomina relatif dan sangat produktif untuk membentuk konstruksi perelatifan sehingga klausa relatif disamakan dengan kata yang (Hogbin dan Song, 2007: 205).

Sementara itu, Alotaibi (2016: 58) mengatakan bahwa klausa relatif merupakan jenis klausa bawahan yang mengubah kata benda yang disematkan pada klausa utama. Fungsi utamanya adalah untuk memisahkan bagian-bagian seperti subjek, kata benda, peristiwa, sesuai dengan pesan yang terdapat dalam kalimat.

Kajian penelitian ini adalah penggunaan klausa relatif pada pembelajar BIPA. Unsur kajiannya tentu berkaitan dengan bahasa Indonesia bagi penutur asing. Dalam hal ini, akan 
terlihat bagaimana bahasa Indonesia bagi penutur asing (BIPA) dalam pembelajaran bahasa kedua. Soviaty (2010: 17) mengungkapkan bahwa istilah bahasa kedua atau second language digunakan untuk mendeskripsikan bahasa-bahasa yang penguasaannya setelah masa kanak-kanak awal termasuk bahasa ketiga atau bahasa-bahasa lain yang dipelajari setelah itu. Bahasa-bahasa yang dipelajari tersebut dinamai dengan bahasa target. Bahasa kedua dapat dikatakan bahasa selain bahasa ibu. Pemerolehan bahasa kedua sebagian besar mengikutsertakan dan membutuhkan beberapa proses pembelajaran di kelas formal (Mitchell \& Myles, 2001: 11-16).

Adapun beberapa penelitian yang relevan dengan penelitian ini adalah sebagai berikut. Penelitian yang dilakukan oleh Suharsono (2015) dengan judul Pemerolehan Klausa Relatif pada Pembelajar BIPA: Kajian Bahasa-Antara. Penelitian ini meneliti tentang pemerolehan klausa relatif pembelajar BIPA tingkat madya yang meliputi bentuk klausa relatif, urutan pemerolehan klausa relatif, dan pengaruh penggunaan strategi belajar bahasa terhadap pemerolehan klausa relatif. Simpulan penelitian Suharsono adalah urutan pemerolehan klausa relatif menggambarkan pula urutan penguasaan dan tingkat kesulitan setiap tipe maupun penggunaan strategi belajar bahasa yang dilaksanakan secara sadar kemudian memungkinkan pemerolehan klausa relatif dapat lebih cepat.

Selain di atas, penelitian yang relevan dilakukan oleh Zhiwen Feng (2013) dengan judul "Functional Grammar and Its Implications for English Teaching and Learning". Penelitian tersebut meneliti dan menganalisa isu-isu seperti sifat tata bahasa fungsional, konsep-konsep inti dari tata bahasa fungsional, perbedaan mendasar antara tata bahasa tradisional dan tata bahasa fungsional kemudian implikasi dari mengajar dan belajar bahasa Inggris. Pada dasarnya, tata bahasa fungsional dapat membantu siswa EFL untuk mencapai keberhasilan dalam bidang studi lain seperti sejarah dan ilmu pengetahuan. Selain signifikansinya dalam proses belajar mengajar, tata bahasa fungsional telah

Berdasarkan latar belakang di atas, maka masalah yang akan dibahas dalam penelitian ini adalah bentuk penggunaan klausa relatif pembelajar BIPA kelas darmasiswa level akademik di UPT Bahasa UNS dan tipe kesalahan penggunaan klausa relatif pembelajar BIPA kelas darmasiswa level akademik di UPT Bahasa UNS. Adapun judul yang diangkat penelitian ini adalah Penggunaan Klausa Relatif pada Pembelajar BIPA di UPT Bahasa Universitas Sebelas Maret Surakarta. 


\section{METODE PENELITIAN}

Penelitian ini adalah deskriptif kualitatif. Hal ini sesuai dengan pendapat (Moleong, 2010: 6) bahwa penelitian kualitatif bermaksud untuk memahami kejaidan tentang apa yang dialami oleh subjek penelitian seperti perilaku, persepsi, motivasi, tindakan dengan mendiskripsikan dalam bentuk kata-kata dan memanfaatkan berbagai metode alamiah.

Penelitian ini dilaksanakan di UPT Bahasa Universitas Sebelas Maret (UNS) Surakarta di kelas darmasiswa level akademik selama satu bulan, yakni pada bulan Maret 2017. Data penelitian ini terdiri atas data tulis dan data lisan. Data tulis menjadi data primer, yakni kalimat-kalimat dalam karangan pembelajar BIPA yang didalamnya terdapat klausa relatif. Kemudian, data lisan menjadi data sekunder, yakni tuturan-tuturan pembelajar BIPA yang didalamnya terdapat klausa relatif.

Sumber data dalam penelitian ini meliputi informan (pengajar BIPA dan pembelajar BIPA), peristiwa yaitu kegiatan pembelajaran bahasa Indonesia bagi penutur asing kelas darmasiswa level akademik di UPT Bahasa Universitas Sebelas Maret Surakartadan dokumen. Dokumen yang digunakan sebagai sumber data, yakni karangan siswa. Pengajar BIPA yang dijadikan sebagai sumber data memiliki inisial Di berasal dari Kartasura. Kemudian, pembelajar BIPA meliputi Us (Thailand), Hy (Korea), My (Vietnam), Al (Vietnam), Ln (Vietnam), Li (Filipina), Ol (Polandia), Ad (Meksiko), Ev (Timor Leste), dan Ko (Jepang).

Teknik pengumpulan data dalam penelitian adalah metode simak. Kemudian teknik lanjutan dari metode simak, yaitu teknik catat. Selanjutnya, peneliti menggunakan metode wawancara. Wawancara yang dilakukan berkaitan dengan penggunaan klausa relatif pada pembelajar BIPA kelas darmasiswa level akademik selama proses pembelajaran. Wawancara dilakukan kepada informan seperti pengajar BIPA dan pembelajar BIPA kelas darmasiswa level akademik UPT Bahasa UNS. Keabsahan data dijaga dengan triangulasi. Triangulasi artinya pengecekan data dengan berbagai sumber dan berbagai waktu (Sugiyono, 2008: 125). Triangulasi yang digunakan penelitian ini adalah triangulasi data, metode, dan review informan Teknik analisis data yang digunakan dalam penelitian ini adalah metode agih. Kemudian, teknik lanjutan berupa teknik ganti, teknik lesap, dan teknik ubah ujud. 


\section{HASIL DAN PEMBAHASAN}

\section{Bentuk Penggunaan Klausa Relatif}

Data yang dianalis berasal dari data lisan dan tulis. Data lisan berupa tuturan-tuturan yang didalamnya terdapat klausa relatif. Selama empat pertemuan dalam proses pengamatan maka diperoleh data lisan sebanyak 18 data. Kemudian, ada empat jenis karangan yang dihasilkan oleh pembelajar BIPA kelas darmasiswa level akademik UPT Bahasa UNS, yaitu karangan surat, karangan deskripsi, eksposisi, dan persuasi. Berdasarkan empat jenis karangan tersebut diperoleh 30 data tulis. Berdasarkan jumlah data tersebut, ada 17 data yang mengalami kesalahan dan sisanya benar.

Klausa relatif ditandai dengan kata perelatif yang. Jenis klausa ini berfungsi untuk mengubah kata benda yang disematkan pada klausa uatama (Alotaibi (2016: 58). Contohnya dalam kalimat Mary tersenyum pada anak-anak yang tidak melakukan pekerjaan rumah mereka. Kalimat tersebut menggunakan kata perelatif yang. Pronomina relatif yang ialah penentu bagi unsur atau bagian yang direlatifkan. Berdasarkan unsur yang direlatifkan terdapat lima tipe klausa relatif, yaitu 1) klausa relatif yang merelatifkan subjek, 2) klausa relatif yang merelatifkan objek, 3) klausa relatif yang merelatifkan unsur termilik, 4) klausa relatif yang menghilangkan unsur nomina, dan 5) klausa relatif yang merelatifkan predikat (DeCapua, 2008: 319).

\section{1) Klausa relatif yang merelatifkan subjek}

Tipe klausa relatif yang merelatifkan subjek dalam karangan dan tuturan pembelajar BIPA yang ditemukan dalam penelitian ini berjumlah 20 data, akan tetapi hanya 6 data yang dipaparkan dalam kajian, yakni sebagai berikut.

(1) Ada bau yang orang Nusa Tenggara sangat suka, namanya durian. (1/Li/DT/27 Maret 2017)

Konstruksi klausa relatif pada data (1) adalah bau yang orang Nusa Tenggara sangat suka, namanya durian. Nomina intinya adalah bau, klausa relatifnya adalah orang Nusa Tenggara sangat suka, dan kata perelatif yang. Dalam hal ini, kata perelatif yang pada data (1) dapat dikatakan merelatifkan subjek karena hanya merelatifkan satu argumen, yakni bau sebagai subjek atau nomina inti. Selain itu, kata perelatif yang dalam kalimat tersebut berada di belakang subjek. sehingga data (1) dapat digolongkan klausa relatif tipe merelatifkan subjek.

(2) Banyak zat yang lain seperti kalsium, vitamin c, lemak, fosfor, zat besi. (2/Ln/DT/29 Maret 2017) 
Konstruksi klausa relatif pada data (2) di atas adalah zat yang lain seperti kalsium, vitamin c, lemak, fosfor, zat besi. Nomina inti dalam data (2) adalah zat, klausa relatif berupa lain seperti kalsium, vitamin c, lemak, fosfor, zat besi, dan kata perelatifnya adalah yang. Kata perelatif yang hanya merelatifkan satu argumen, yakni zat yang berfungsi sebagai subjek atau nomina inti. Kemudian, kata perelatif yang tersebut berada di belakang subjek sehingga data (2) dapat digolongkan klausa relatif tipe merelatifkan subjek.

(3) Apakah anda memiliki kesempatan untuk melihat upacara yang lain di Indonesia? (3/Al/DT/7 Maret 2017)

Data (3) di atas mempunyai urutan konstruksi klausa relatif yang sama dengan data sebelumnya. Konstruksi data (3) ialah upacara yang lain di Indonesia. Nomina intinya adalah upacara, klausa relatifnya ialah lain di Indonesia, dan kata perelatifnya adalah yang. Kata perelatif yang hanya merelatifkan satu argumen, yakni upacara yang berfungsi sebagai subjek atau nomina inti. Kemudian, kata perelatif yang tersebut berada di belakang subjek sehingga data (3) dapat digolongkan klausa relatif tipe merelatifkan subjek.

(4) Pakar Psychology Dr Cha De Lin di majalah IPT yang tersohor di seluruh dunia, mempublikasikan sebuah artikel yang menggegerkan dunia. (4/My/DT/4 April 2017)

Data (4) tersebut mempunyai dua konstruksi: (1) pakar Psychology Dr Cha De Lin di majalah IPT yang tersohor di seluruh dunia, (2) sebuah artikel yang menggegerkan dunia. Konstruksi pertama mempunyai nomina inti berupa pakar Psychology Dr Cha De Lin di majalah IPT, klausa relatifnya tersohor di seluruh dunia, dan kata perelatifnya yang. Kemudian, konstruksi kedua mempunyai nomina inti sebuah artikel, klausa relatifnya menggegerkan dunia, dan kata perelatifnya yang. Kedua konstruksi tersebut memiliki unsur konstruksi yang benar sesuai dengan kaidah penggunaan klausa relatif bahasa Indonesia tipe yang merelatifkan subjek.

Selanjutnya, hal yang sama juga terdapat pada data (5) berikut.

(5) Spa My Beauty selalu menjadi tempat pelayanan kecantikan yang terkenal di banyak kota. (5/My/DT/4 April 2017)

Konstruksi klausa relatif data (5) di atas adalah tempat pelayanan kecantikan yang terkenal di banyak kota. Nomina intinya berupa tempat pelayanan kecantikan, klausa relatifnya adalah terkenal di banyak kota, dan kata perelatifnya yang. Kata perelatif yang hanya merelatifkan satu argumen, yaitu tempat pelayanan kecantikan yang memiliki fungsi sebagai subjek atau nomina inti. Kemudian, kata perelatif yang tersebut berada di belakang 
subjek atau nomina inti sehingga data (5) dapat digolongkan klausa relatif tipe merelatifkan subjek.

(6) Jenis musik yang paling cocok adalah jenis musik klasik. (6/Li/DT/4 April 2017)

Konstruksi klausa relatif data (6) di atas adalah jenis musik yang paling cocok adalah jenis musik klasik. Nomina intinya berupa jenis musik, klausa relatifnya adalah paling cocok adalah jenis musik klasik, dan kata perelatifnya yang. Kata perelatif yang tersebut hanya merelatifkan satu argumen, yakni jenis musik yang berfungsi sebagai subjek atau nomina inti. Kemudian, kata perelatif yang tersebut berada di belakang subjek atau nomina inti sehingga data (6) dapat digolongkan klausa relatif tipe merelatifkan subjek.

Selain contoh keenam data di atas, masih ada 14 data lagi yang memiliki kesamaan dalam unsur konstruksi tipe klausa relatif yang merelatifkan subjek. Untuk mengikuti kaidah keefektifan analisis maka hanya ada 6 data tipe klausa relatif yang merelatifkan subjek yang dipaparkan sebagai sampel.

\section{2) Klausa relatif yang merelatifkan objek}

Berdasarkan data yang diperoleh, ada tujuh data yang mennjukkan tipe klausa relatif yang merelatifkan objek. Perhatikan data-data berikut ini.

(7) Bunyi-bunyi yang ditambahkan kepada kata dasar untuk menambahkan makna pada kata dasarnya. (7/Ev/DT/29 Maret 2017)

Data (7) adalah merelatifkan objek yang telah dijadikan subjek dengan adanya bentuk pemasifan. Pada dasarnya, data (7) berasal dari kalimat bunyi-bunyi yang ada pada kata dasar, maka menambahkan makna pada kata dasarnya. Objek tersebut dapat direlatifkan setelah terjadi proses pemasifan, yakni mengubah objek menjadi subjek.

(8) Kecelakaan yang menimbulkan korban jiwa dari pengendara sepeda motor disebabkan oleh luka kepala. (8/Al/DT/4 April 2017).

Data (8) adalah merelatifkan objek yang telah dijadikan subjek dengan adanya bentuk pemasifan. Pada dasarnya, data (8) berasal dari kalimat luka kepala menjadi salah satu penyebab korban jiwa dari pengendara sepeda motor dari kecelakaan. Objek tersebut dapat direlatifkan setelah terjadi proses pemasifan, yakni mengubah objek menjadi subjek. Perlu diketahui bahwa klausa relatif yang merelatifkan objek terjadi apabila adanya proses pemasifan terlebih dahulu.

(9) Kemudian ukuran yang ada dilukis sesuai perhitungan. (9/Us/DT/29 Maret 2017) 
Data (9) adalah merelatifkan objek yang telah dijadikan subjek dengan adanya bentuk pemasifan. Pada dasarnya, data (9) berasal dari kalimat kemudian, melukis ukuran yang ada sesuai perhitungan. Objek tersebut dapat direlatifkan setelah terjadi proses pemasifan, yaitu dengan mengubah objek menjadi subjek. Perlu diketahui bahwa klausa relatif yang merelatifkan objek terjadi apabila adanya proses pemasifan terlebih dahulu.

(10) Setelah itu, kertas yang telah digunting tadi digunakan sesuai aturan. (10/Us/DtT/ 29 Maret 2017)

Data (10) adalah merelatifkan objek yang telah dijadikan subjek dengan adanya bentuk pemasifan. Pada dasarnya, data (10) berasal dari kalimat menggunakan kertas yang telah digunting tadi sesuai aturan. Objek tersebut dapat direlatifkan setelah terjadi proses pemasifan, yakni bentuk mengubah objek menjadi subjek. Perlu diketahui bahwa klausa relatif yang merelatifkan objek terjadi apabila ada proses pemasifan terlebih dahulu.

Selanjutnya, masih ada data (11) dan (12) yang mempunyai unsur konstruksi yang sama dengan data (7), (8), (9), dan (10).

(11) Kerajaan-kerajaan yang ada di Indonesia hanya dipimpin oleh satu orang. (11/Ev/DL/ 15 Maret 2017)

Data (11) adalah merelatifkan objek yang telah dijadikan subjek melalui pemasifan. Pada dasarnya, data (11) berasal dari kalimat hanya satu orang yang memimpin kerajaankerajaan yang ada di Indonesia. Objek tersebut dapat direlatifkan setelah terjadi proses pemasifan, yakni pengubahan objek menjadi subjek. Perlu diketahui bahwa klausa relatif yang merelatifkan objek terjadi apabila ada proses pemasifan.

(12) Di Vietnam jalan-jalan diberi nama menurut nama pahlawan yang terkenal. (12/My/DL/15 Maret 2017)

Data (12) adalah merelatifkan objek yang telah dijadikan subjek dengan adanya bentuk pemasifan. Pada dasarnya, data (12) berasal dari kalimat nama pahlawan yang terkenal menjadi nama jalan-jalan di Vietnam. Objek tersebut dapat direlatifkan setelah terjadi proses pemasifan, yakni mengubah objek menjadi subjek. Perlu diketahui bahwa klausa relatif yang merelatifkan objek terjadi apabila ada proses pemasifan terlebih dahulu.

\section{3) Klausa relatif yang merelatifkan unsur termilik}

Ada satu data yang menjelaskan tipe klausa relatif yang merelatifkan unsur termilik. Data tersebut terlihat pada data (13) berikut ini.

(13) Dia mempunyai wajah yang bentuknya oval. (13/Al/DT/27 Maret 2017) 
Konstruksi klausa relatif data (13) adalah wajah yang bentuknya oval. Nomina intinya adalah wajah, klausa relatifnya adalah bentuknya oval, dan kata perelatifnya adalah yang. Pronomina nya pada data (13) di atas menjelaskan kepemilikan dari nomina inti wajah yang direlatifkan oleh kata yang.

(14) Dia mempunyai satu tanda lalat yang besar di alisnya. (14/Al/DT/27 Maret 2017)

Data (14) di atas mempunyai urutan konstruksi yang sama dengan data (14), yakni tanda lalat yang besar di alisnya. Nomina inti dari klausa tersebut adalah tanda lalat, klausa relatifnya adalah besar di alisnya, dan kata perelatifnya ialah yang. Pronomina nya yang bergabung dengan kata alis menjelaskan kepemilikan dari nomina inti tanda lalat yang direlatifkan oleh kata yang.

\section{4) Klausa relatif yang menghilangkan unsur nomina}

Sesuai data yang telah direduksi, hanya satu data yang menggambarkan tipe klausa relatif yang mneghilangkan unsur nomina. Tipe tersebut dapat dilihat pada data (15) berikut ini.

(15) Ada dua kamera. Yang satu ada di depan atas, yang lain ada di belakang. (15/Hy/DT/27 Maret 2017)

Tipe-tipe klausa relatif dalam bahasa Indonesia sesungguhnya mempunyai satu unsur.

Data (15) di atas telah mengalami pelesapan unsur nomina. Unsur nomina kamera pada kalimat Ada dua kamera, mengalami pelesapan pada kalimat Yang satu ada di depan atas, yang lain ada di belakang. Kata perelatif yang berdiri pada awal kalimat yang sebenarnya berdiri dibelakang subjek atau unsur nomina inti. Apabila nomina itu ada, kalimatnya menjadi "Ada dua kamera. Kamera yang satu ada di depan atas dan kamera yang lain ada di belakang”.

Berdasarkan jumlah tipe klausa relatif, hanya empat tipe klausa relatif yang ditemukan pada data. Tipe klausa relatif yang merelatifkan predikat tidak ditemukan pada data baik data lisan maupun tulis.

Penjelasan berkaitan dengan penggunaan klausa relatif bagi pembelajar BIPA tidak terlepas dari bentuk-bentuk kesalahan karena dalam situasi pemerolehan bahasa kedua, pembelajar berkemungkinan untuk melakukan kesalahan. Kesalahan tersebut disebabkan oleh ketidaktahuan atau belum dikuasainya kaidah penggunaan klausa relatif dalam bahasa Indonesia yang benar. 
Berikut ini diuraikan bentuk-bentuk kesalahan yang ditemukan dalam tuturantuturan pembelajar BIPA dan kalimat-kalimat dalam karangan pembelajar BIPA yang masuk kelas darmasiswa level akademik di UPT Bahasa UNS. Penggunaan kata perelatif yang pada klausa memiliki kesamaan terhadap penggunaan konjungsi seperti yang diungkapkan oleh Faizah (2009: 77) dalam penelitiannya bahwa konjungsi menjadi alat untuk menghubungkan antarunsur linguistik. Pemakaiannya perlu memerhatikan kelogisan pikiran dari dua unsur linguistik yang dihubungkan sehingga tercipta kepaduan.

\section{Tipe Kesalahan Penggunaan Klausa Relatif pada Pembelajar BIPA Kelas Darmasiswa Level Akademik}

Kesalahan yang terjadi pada tataran klausa biasanya terjadi pada bagian urutan kata. Dalam hal ini, kesalahan penggunaan klausa relatif salah satunya salah peletakkan urutan kata peelatif yang. Hal tersebut diperkuat oleh penelitian Indrowaty (2015) yang menyimpulkan bahwa kesalahan sintaksis pada tataran frasa dan klausa pada mahasiswa terjadi pada urutan kata yang kurang benar.

Kesalahan yang ditemukan pada penelitian ini adalah sebagai berikut. Pertama, ada kesalahan secara umum berkaitan dengan tidak digunakannya pronomina relatif yang. Pada tipe kesalahan ini, pembelajar BIPA tidak menggunakan pronomina relatif yang yang seharusnya digunakan dalam tuturan. Kesalahan tersebut dapat dilihat dalam contoh kalimat (16) dan (17) berikut ini, kemudian kalimat (16a) dan (17a) sebagai pembetulannya.

(16) Di Korea ada banyak dinasti. Dinasti paling terkenal adalah Dinasti Joseon. (16/Hy/DL/13 Maret 2017)

Data (16) tersebut mengalami kesalahan karena tidak adanya kata perelatif yang di depan kata paling. Sesuai dengan intuisi bahasa, data (16) apabila tidak ada kata perelatif yang maka hasilnya kalimat yang tidak berterima. Oleh karena itu, kalimat tersebut akan menjadi berterima apabila diberi kata perelatif yang seperti pada kalimat (16a) Di Korea ada banyak dinasti. Dinasti yang paling terkenal adalah Dinasti Joseon. Data berikutnya adalah sebagai berikut.

Hal serupa terlihat pada data (17) berikut ini.

(17) Makanan tradisional adalah makanan masak diri sendiri. (17/Al/DT/29 Maret 2017).

Data (17) di atas mempunyai unsur yang sama seperti data (16). Kalimat pada data (17) mengalami kesalahan artinya kalimat tersebut kurang berterima karena tidak adanya kata perelatif yang. Seharusnya, kata perelatif yang disisipkan antara kata makanan dan 
masak. Kemudian, kata masak pun perlu diubah menjadi pasif, yakni dimasak supaya kalimat tersebut lebih bisa diterima. Pembenaran dari kalimat (17) adalah (17a) Makanan tradisional adalah makanan yang dimasak oleh diri sendiri.

Kajian pronomina relatif yang ini sejalan dengan hasil penelitian Rugaiyah (2009: 87) yang menyimpulkan bahwa kata pemarkah atau penggolong any dalam bahasa Inggris dapat muncul pada jenis kalimat tunggal maupun majemuk sesuai kajian struktural dalam klausa. Sema halnya dengan pronomina perelatif kata yang dalam bahasa Indonesia pun dapat muncul di kalimat tunggal maupun majemuk.

Kedua, kesalahan yang ditemukan dalam tuturan pembelajar BIPA berupa ketidaksesuaian penempatan demonstrativa itu. Pada dasarnya, dalam klausa relatif ada kemungkinan muncul demonstrativa itu. Dalam klausa relatif, demonstrativa itu memiliki fungsi sebagai pembatas bagi frasa nomina yang direlatifkan. Artinya, unsur yang berada sebelum kata itu adalah frasa tersendiri sedangkan unsur yang berada sesudah kata itu adalah kata atau frasa lain. Kesalahan yang ditemukan adalah demonstrativa itu tidak diletakkan pada bagian akhir klausa relatif, melainkan di belakang nomina atau frasa nomina yang direlatifkan. Berikut ini data (18) merupakan contoh kesalahan dari tipe kedua sedangkan kalimat (18a) merupakan kalimat pembetulanya.

(18) Jika pabrik itu tidak ada yang pakai alat saring bisa didenda. (18/Ln/DL/13 Maret 2017)

Kalimat pada data (18) di atas mengalami kesalahan pada peletakkan demonstrativa itu. Seharusnya, pronomina itu diletakkan setelah kata saring sehingga kalimat lebih berterima sehingga kalimat tersebut akan benar apabila diubah menjadi (18a) Jika pabrik tidak ada yang pakai alat saring itu, bisa didenda.

Ketiga, kesalahan yang ditemukan adalah kesalahan pada klausa relatif yang merelatifkan subjek. Jenis kesalahan ini terletak dalam penggunaan afiks pada verba aktif. Verba tersebut seharusnya berafiks, tetapi pada kenyataannya tidak diberi afiks. Berikut ini data yang menunjukkan kesalahan tipe ini.

(19) Saya ingin tahu apa anda bertiga sudah memakai pakaian di perkawinan itu dan bagaimana anda tahu apa yang harus bilang dengan mempelai. (19/Al/DT/7 Maret 2017).

Kesalahan pada data (19) terletak pada klausa relatif harus bilang dengan mempelai. Sesudah kata perelatif yang, yakni kata bilang seharusnya ditambah prefiks di-sehingga kalimat tersebut akan lebih berterima setelah ada proses pemasifan. Pembenarannya seperti 
kalimat (19a) Saya ingin tahu apa anda bertiga sudah memakai pakaian di perkawinan itu dan bagaimana anda tahu apa yang dibilang oleh mempelai. Kesalahan yang sama ditemukan pada data berikut ini.

(20) Dia terbuat dari plastik yang bisa daur ulang. (20/Ln/DT/27 Maret 2017)

Kesalahan kalimat pada data (20) sama halnya dengan data (19), yakni terletak pada klausa relatif bisa daur ulang. Nomina daur ulang membuat kalimat tersebut kurang berterima. Seharusnya, nomina daur ulang ditambah prefiks di-. Disamping itu, ada kesalahan selain klausa relatif yang ditemukan pada data (20), yaitu subjek dia seharusnya itu karena pronomina tersebut dimaksudkan untuk benda plastik. Dengan demikian, pembetulan data (20) menjadi (20a) Dia terbuat dari plastik yang bisa didaurulang.

Kesalahan klausa relatif yang merelatifkan subjek juga terlihat pada data (21) berikut.

(21) Mungkin membuat papan yang ditulis "Dilarang membuang sampah di sini!". (21/Li/DL/13 Maret 2017)

Jenis kesalahan tersebut sama halnya dengan data (19) dan (20) bahwa terletak pada penggunaan afiks pada verba aktif. Pada contoh data (21) verba ditulis seharusnya tertulis. Verba tertulis memiliki makna sudah ditulis. Selain itu, secara kaidah pemasifan kata ditulis harus diikuti oleh subjek dibelakangnya. Oleh karena itu, data (21) seharusnya menjadi (21a) Mungkin membuat papan tulis yang tertulis "Dilarang membuang sampah di sini!" Hal yang sama terlihat pada data (22) berikut ini.

(22) Zaman dahulu ada negara yang terdirikan dari kerajaan-kerajaan. (22/My/DL/15 Maret 2017)

Data (22) mempunyai kesalahan pada penggunaan verba terdirikan. Verba tersebut seharusnya tidak memerlukan akhiran -kan cukup dengan awalan ter- saja. Sesuai dengan tipe klausa relatif yang merelatifkan subjek, maka penggunaan akhiran -kan apabila digunakan setelah kata perelatif yang kurang berterima. Hal tersebut justru dapat mengubah makna dari kalimat secara lengkap. Data (22 tersebut seharusnya diubah menjadi (22a) Zaman dahulu ada negara yang terdiri dari kerajaan-kerajaan.

Selanjutnya, data (23) pun mengalami kesalahan yang sama.

(23) Apakah kalian ada kesempatan yang bisa lihat upacara lain? (23/Ko/DT/7 Maret 2017) 
Data (23) di atas mempunyai kesalahan pada pemilihan verba bisa. Penggunaan kata bisa justru menimbulkan kerancuan. Kemudian, kata lihat juga kurang berterima karena belum sesuai dengan kaidah tipe klausa relatif yang merelatifkan subjek. Kata bisa lebih baik diganti dengan kata baik, kata lihat perlu diganti dengan kata melihat, dan perlu adanya penambahan adverbia untuk sehingga klausa akan lebih diterima. Pembenarannya seharusnya menjadi (23a) Apakah kalian ada kesempatan yang baik untuk melihat upacara lain?

Keempat, kesalahan pada klausa relatif yang merelatifkan objek. Kesalahan jenis ini dibagi atas empat subtipe berdasarkan pada bentuk verba pasif yang berada di belakang pronomina relatif yang. Perelatifan objek dalam bahasa Indonesia menyebabkan verba dalam klausa relatif berubah pasif. Di sini, verba pasif dibedakan menjadi dua tipe yakni verba pasif berafiks $d i$ - dan verba pasif persona. Empat subtipe, yaitu: (a) kesalahan penggunaan afiks, (b) kesalahan penempatan persona, (c) kesalahan penggunaan bentuk verba pasif persona, (d) kesalahan penempatan adverbia pada bentuk pasif persona. Berikut ini penjelasan secara rinci berdasarkan data yang ada.

Subtipe pertama adalah penggunaan afiks pada verba pasif $d i$-. Kesalahan ini adalah kesalahan yang terjadi karena verba tidak berprefiks atau menggunakan prefiks $d i$ - tetapi belum tepat. Perhatikan data (24) berikut ini.

(24) Saya bisa tahu tentang upacara akad nikah yang ada di Jawa, menurut adat orang jawa, dan proses-proses yang menjalankan upacara akad nikah. (24/Ev/DT/7 Maret 2017)

Kata kerja menjalankan pada data (24) masih kurang tepat seharusnya awalan mediganti dengan awalan di-, yakni dijalankan. Seharusnya kalimat diubah menjadi (24a) Saya bisa tahu tentang upacara akad nikah yang ada di Jawa, menurut adat orang jawa, dan proses-proses yang dijalankan pada akad nikah.

\section{(25) Ada tempat yang buat untuk kain batik.(25/Ln/DL/13 Maret 2017)}

Kesalahan yang terjadi pada data (25) di atas terletak pada penggunaan kata buat setelah kata perelatif yang. penggunaan kata buat menimbulkan keambiguan makna. sesuai teori Decapia (2008) bahwa setelah kata perelatif yang perlu digunakan kata verba berawalan di atau pasif untuk membentuk makna yang kalimat tersebut. kemudian kalimat tersebut ditemukan kata untuk sehingga telah jelas bahwa kalimat pada data (25) perlu kata yang dipasifkan. oleh karena itu, data (25) perlu dibenarkan menjadi (25a) Ada tempat yang dibuat untuk kain batik. 
(26) Orang Vietnam mengatakan kerajaan-kerajaan yang membangun Vietnam adalah raja itu sendiri. (26/Li/DL/15 Maret 2017)

Data (26) di atas telah ditemukan penggunaan kata membangun setelah kata perelatif yang sehingga menyebabkan kalimat tersebut tidak berterima. Seharusnya, sesudah klausa relatif pada kalimat (26) diubah menjadi pasif, objek diubah menjadi subjek dan afiks mediubah menjadi afiks di- sehingga klausa tersebut menjadi kalimat berterima. Pembenarannya seperti pada kalimat (26a) Negara Vietnam itu didirikan oleh raja-raja Vietnam.

Kesalahan tipe ini dapat pula terlihat pada data (27) berikut.

(27) Kamu tahu makanan Indonesia yang pakai kentang dan hati ayam? (27/Ko/DL/16 Maret 2017)

Sama halnya dengan data (26), data (27) di atas mengalami kesalahan pada penggunaan kata pakai sehingga kalimat tersebut tidak berterima. Kata pakai perlu diubah menjadi kata lain yang lebih berterima, seperti berbahan. Verba yang digunakan setelah kata perelatif yang adalah berbahan. Kemudian, data (27) tersebut perlu penambahan kata tugas dari. Oleh karena itu, data (27) dapat berterima apabila diubah menjadi kalimat (27a) Kamu tahu makanan Indonesia yang berbahan dari kentang dan hati ayam?

Subtipe kedua adalah penempatan adverbia pada bentuk pasif persona. Dalam bahasa Indonesia, adverbia yaitu kata yang dapat mendampingi adjektiva, verba, numeralia, atau proposisi dalam konstruksi sintaksis (Kridalaksana, 1986: 79). Pada konstruksi pasif persona seperti pada klausa buku itu sudah saya ambil. Kesalahan yang dilakukan oleh pembelajar BIPA adalah mereka menempatkan adverbia di antara pronomina persona dan verba seperti data (28) berikut ini. Kemudian, data (17a) adalah pembetulannya.

(28) Teh tarik adalah minuman yang saya paling suka di Thailand. (28/Us/DT/29 Maret 2017).

Data (28) tersebut terlihat bahwa penempatan pronomina saya kurang tepat, seharusnya berada langsung di depan verba sesuai intuisi bahasa dan kaidah penggunaan klausa relatif bahasa Indoensia yang benar. Oleh karena itu, pembenaran data (28) menjadi (28a) Teh tarik adalah minuman yang paling saya suka di Thailand.

Kesalahan yang sama juga terlihat pada data (29) bahwa adanya kesalahan penempatan adverbia pada bentuk pasif persona.

(29) Kalau ada yang satu hari tidak boleh menggunakan mobil, maka itu dapat digunakan untuk mengurangi pencemaran udara. (29/Ol/DL/13 Maret 2017) 
Data (29) tersebut mengalami kesalahan pada penempatan adverbia tidak. Dalam hal ini, adverbia tidak seharusnya berada di belakang persis kata perelatif yang. Oleh karena itu, untuk membentuk penempatan adverbia yang benar dan lebih berterima sesuai instuisi bahasa, maka data (29) seharusnya diubah menjadi (29a) Kalau ada satu hari yang tidak boleh menggunakan mobil, maka itu dapat digunakan untuk mengurangi pencemaran udara.

(30) Kita sudah membunuh ekosistem yang sebagai sumber kekayaan negara. (30/Ev/DT/4 April 2017)

Data (30) terlihat ada kesalahan pada penempatan adverbia sebagai. Apabila kata sebagai tersebut diletakkan setelah kata perelatif yang maka tidak sesuai dengan kaidah penulisan klausa relatif pada tipe klausa relatif yang merelatifkan objek terutama penempatan adverbia. Hal ini yang menyebabkan data (30) kurang berterima. Oleh karena itu, data (30) perlu ditambahi kata berfungsi setelah kata perelatif yang sehingga akan membentuk susunan yang benar. Oleh karena itu, data (30) seharusnya diubah menjadi (30a) Kita sudah membunuh ekosistem yang berfungsi sebagai sumber kekayaan negara.

(31) Kita sudah membunuh ekosistem yang sebagai sumber kekayaan negara. (31/Ev/DT/ 4 April 2017)

Data (31) di atas mempunyai kesalahan yang sama dengan data sebelumnya, yakni terlihat pada penggunaan kata sebagai setelah kata perelatif yang. Penggunaan kata sebagai menyebabkan data (31) tidak berterima karena menimbulkan makna kalimat yang membingungkan. Data (31) tersebut akan berterima apabila kata sebagai diubah menjadi kata merupakan. Oleh karena itu, pembenarannya menjadi data (31a) Kita sudah membunuh ekosistem yang merupakan sumber kekayaan negara.

Subtipe ketiga, kesalahan penempatan persona pada verba pasif persona. Perhatikan data berikut ini.

(32) Fotomu yang dikirimkan kepada saya yang luar biasa. (32/Ln/DT/ 7 Maret 2017)

Jenis kesalahan data (32) tersebut disebabkan oleh kurangnya persona sebelum verba dikirimkan. Persona kamu perlu ditambahkan karena pembelajar BIPA menggunakan kaidah akhiran -kan. Selain itu, verba dikirimkan kurang berterima penggunaannya. Verba tersebut akan lebih berterima apabila awalan di- dihilangkan. Kemudian, relatif yang sebelum kata luar biasa seharusnya dihilangkan juga. Keberadaan kata perelatif yang yang 
kedua justru membuat kalimat tidak efektif. Pembetulan data (32) tersebut menjadi (32a) Fotomu yang kamu kirimkan kepada saya luar biasa.

Analisis tentang tipe-tipe klausa relatif di atas dipertegas dengan teori Klingenman (1987) yang mengungkapkan bahwa dalam bahasa Indonesia frasa nomina yang berfungsi sebagai subjek yang dapat secara langsung direlatifkan. Kemudian frasa nomina lain seperti objek, predikat, pelengkap, dan keterangan dapat diberi sematan apabila diubah terlebih dahulu menjadi kalimat pasif atau mengalami proses pemasifan.

Hasil analisis kesalahan penggunaan klausa relatif pada pembelajar BIPA sesuai tipe perelatifannya dapat digunakan sebagai acuan dalam menentukan persentase tingkat penguasaan penggunaan klausa relatif. Tingkat penguasaan tersebut menggambarkan tipe klausa relatif mana yang mampu dikuasai oleh pembelajar BIPA. Persentase kesalahan tersebut dijelaskan pada tabel di bawah ini.

\section{Tabel 1. Persentase Pemerolehan menurut Tipe Klausa Relatif}

\begin{tabular}{|c|c|c|c|c|c|}
\hline Tipe Kesalahan & $\begin{array}{l}\text { Jumlah } \\
\text { Salah }\end{array}$ & $(\%)$ & $\begin{array}{c}\text { Jumlah } \\
\text { Betul }\end{array}$ & $(\%)$ & $\begin{array}{c}\text { Jumlah } \\
\text { Data }\end{array}$ \\
\hline Tidak adanya kata perelatif yang & 2 & 100 & 0 & 0 & 2 \\
\hline $\begin{array}{l}\text { Kesalahan peletakkan } \\
\text { demonstrativa itu }\end{array}$ & 1 & 100 & 0 & 0 & 1 \\
\hline $\begin{array}{l}\text { Klausa relatif yang merelatifkan } \\
\text { subjek }\end{array}$ & 5 & 18.51 & 22 & 81.48 & 27 \\
\hline $\begin{array}{l}\text { Klausa relatif yang merelatifkan } \\
\text { objek }\end{array}$ & 9 & 60 & 6 & 40 & 15 \\
\hline Merelatifkan unsur termilik & 0 & 0 & 2 & 100 & 2 \\
\hline $\begin{array}{l}\text { Klausa relatif yang menghilangkan } \\
\text { unsur nomina }\end{array}$ & 0 & 0 & 1 & 100 & 1 \\
\hline $\begin{array}{l}\text { Klausa relatif yang merelatifkan } \\
\text { predikat }\end{array}$ & 0 & 0 & 0 & 0 & 0 \\
\hline \multicolumn{5}{|c|}{ Jumlah Data } & 48 \\
\hline
\end{tabular}

Tabel 1 di atas menunjukkan bahwa ada tujuh kriteria tipe kesalahan dalam penggunaan klausa relatif. Berdasarkan ketujuh tipe kesalahan tersebut, ada enam tipe yang ditemukan sedangkan satu tipe, yakni kesalahan pada klausa relatif yang merelatifkan predikat tidak ditemukan pada data. Untuk mendeskripsikan urutan penguasaan penggunaan klausa relatif pada pembelajar BIPA, maka data tersebut perlu diurutkan dari jumlah persennya. Pemerolehan terhadap klausa relatif yang merelatifkan unsur termilik dan kesalahan pada klausa relatif yang menghilangkan unsur nomina menduduki tingkat tertinggi ditunjukkan dengan persentase jumlah benar sebesar 100\%. Kemudian, pemerolehan terhadap klausa relatif yang merelatifkan subjek berada di posisi kedua. Hal 
tersebut ditunjukkan dengan persentase jumlah benar sebesar $81.84 \%$ sedangkan persentase jumlah salah hanya $18.51 \%$. Selanjutnya, pemerolehan terhadap klausa relatif yang merelatifkan objek menduduki tingkat ketiga dengan persentase jumlah benar sebesar $40 \%$ sedangkan persentase jumlah salah $60 \%$. Pada posisi terendah terletak pada pemerolehan terhadap tipe kesalahan tidak adanya kata perelatif yang dan kesalahan peletakkan demonstrativa itu, yakni dengan persentase jumlah benar sebesar $0 \%$ dan jumlah salah sebesar $100 \%$.

Keenam tipe kesalahan tersebut apabila diurutkan maka akan menunjukkan tingkat penguasaan klausa relatif dari yang cepat ke lambat. Berikut ini piramida yang dapat menggambarkan urutan penguasaan klausa relatif pembelajar BIPA baik lisan maupun tulis.

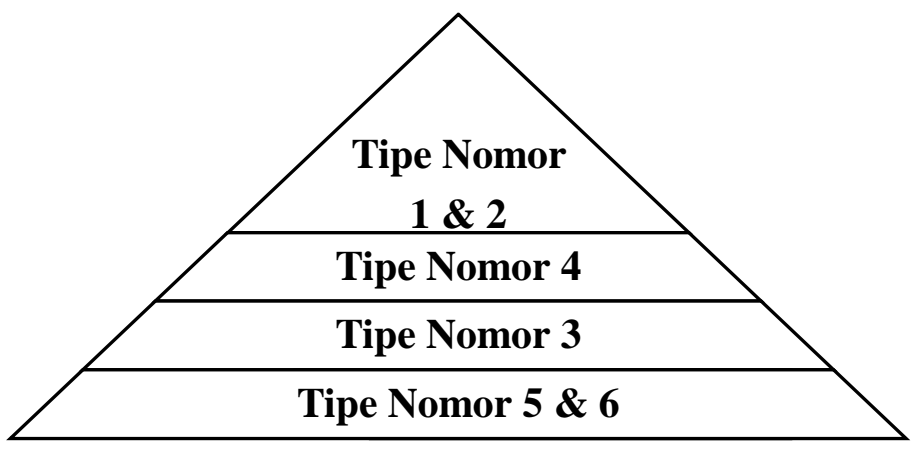

\section{Gambar 1. Piramida Urutan Penguasaan Klausa Relatif}

Berdasarkan piramida di atas, maka dapat diperoleh bahwa penguasaan tingkat pemerolehan tersebut adalah 1) tipe kesalahan pada klausa relatif yang merelatifkan unsur termilik dan kesalahan pada klausa relatif yang menghilangkan unsur nomina, 2) tipe kesalahan pada klausa relatif yang merelatifkan subjek, 3) tipe kesalahan pada klausa relatif yang merelatifkan objek, 4) tipe kesalahan tidak adanya kata perelatif yang dan kesalahan peletakkan demonstrativa itu.

\section{IV.KESIMPULAN}

Berdasarkan pembahasan di atas dapat disimpulkan sebagai berikut. Pertama, bentuk penggunaan klausa relatif menggambarkan pula penguasaan tingkat kesulitan setiap tipe klausa relatif. Hal tersebut dapat dilihat berdasarkan persentase jumlah benar dan jumlah salah dari setiap tipe klausa relatif. Dengan demikian, penguasaan terhadap penggunaan klausa relatif dapat berpengaruh dalam pengembangan materi ajar BIPA. 
Semakin rendah tingkat kesalahan penggunaan klausa relatif maka menunjukkan keberhasilan penggunaan klausa relatif.

\section{REFERENSI}

Alotaibi, Abdullah M. 2016. Examining the Learnability of English Relative Clauses: Evidence from Kuwaiti EFL Learners. Canadian Center of Science and Education, 9 (2): 57-65.

Cook, W.A. 1969. Introduction to Tagmemic Analysis. Londong: Holt International Edition. DeCapua, A. 2008. Grammar for Teachers: A Guide to American English for Native and Non-Native Speakers. New York: Springer.

Downing, Angela dan Philip, Locke. 2006. English Grammar a University Course Second Edition. New York: Routlage.

Ellis, R. 2003. Second Language Acquisition. New York: Oxford University Press.

Elson, Benjamin \& Pickett, Velma. 1969. An Introduction to Morpholog and Syntax. California: Summer Institute of Linguistic.

Faizah, Hasnah. 2011. Konjungsi Klausa Objek dalam Kalimat Subordinatif Bahasa Indonesia. Sosiohumaniora, 13 (1): 76-95.

Feng, Zhiwen. 2013. Functional Grammar and Its for English Teaching and Learning. Journal of English Language Teaching, 6 (10): 86-94.

Gucker, Philip. 1966. Essential English Grammar. New York: Dover Publications, INC.

Hedge, Tricia. 2002. Teaching and Learning in the Language Classroom. Oxford: Oxford University Press.

Indrowaty, Sri Ayu. 2015. Jenis Kesalahan yang Biasa Terjadi dalam Karangan Berbahasa Bahasa Jepang. Diglossia, 7 (1): 33-49.

Keenan, Edward L \& Comrie, Benard. 1977. Noun Phrase Accessibility and Universal Grammar. Linguistic Inquiry, 8 (1): 63-99.

Klingenman, Berg dan Den, Lidy Van. 1987. Klausa Relatif Bahasa Indonesia dan Bahasa Muna dalam Lontara No 34: 5-25. Ujung Pandang: Universitas Hasanuddin.

Kridalaksana, H. 2008. Kamus Lingusitik. Jakarta: Gramedia.

Li, Changyu. 2009. A Research on Second Language Acquisition and College English Teaching. Journal of English Language Teaching, 2(4): 57-60. 
Mallinson, Graham and Barry J Blake. 1981. Language Typology, Cross Linguistik Studies in Syntax. Amsterdam: North Holand Publishing Company.

Mitchell, R \& Myles, F. 2001. Second Language Learning: Key Concepts and Issues. In C. N. Candlin and N. Mercer (Eds). English Language Teaching in Its Social Context: A reader, (11-27). New York: Routledge.

Pike, Knneth L \& Pike, Evelyn G. 1977. Grammatical Analysis. Dallas: Summer Institute of Linguistic \& University of Texas at Arlington.

Richards, Jack C. 1985. Longman Dictionary of Applied Linguistics. Essex: Longman Group Limited.

Rugaiyah. 2009. Pronomina Nonasertive "Any” dalam Bahasa Inggris: Kajian Sintaksis dan Semantis. Sosiohumaniora. 11 (13): 74-89.

Soviaty, Ovi. 2010. Laporan Akhir Pemetaan Pengajaran Bahasa Indonesia bagi Penutur Asing di Asia. Pusat Bahasa.

Sugiyono. 2008. Metode Penelitian Kunatitatif Kualitatif dan R\&D. Bandung Alfabeta.

Suhardi. 2000. Pembelajaran BIPA melalui Kegiatan Wisata. Prosiding KIPBIPA III, hlm. 8. Bandung: Andira.

Suharsono. 2015. Pemerolehan Klausa Relatif pada Pembelajar BIPA: Kajian BahasaAntara. LITERA, 14 (1): 57-74. 